THURSDAY, JUNE 23, I892.

\section{THE NEW LONDON UNIVERSITY.}

$\mathrm{T} \mathrm{N}$ our last issue we laid before our readers a statement of the proposals adopted by the Association for Promoting a Professorial University for London at a meeting held at Burlington House on the I 4 th inst. It may tend to clear the issue if we now briefly compare these proposals with the provisions of the Gresham Charter.

The Gresham Charter seeks to federate two Colleges and ten medicai schools, primarily for examination purposes. Such a University, if created, would have had two competing staffs in the Faculties of Arts and Science and twelve in the Faculty of Medicine. Provision is also made, under certain conditions, for the federation of other institutions, if it can be shown to the satisfaction of the Council-that is, of the Chancellor, the Lord Mayor of London, and the representative members of the Councils of the twoconstituent Colleges and the ten medical schools -that such institutions are on a basis justifying the expectation of permanent existence; that they are under the independent control of their own governing bodies; and that they are reasonably well equipped in some one Faculty. Such a federation, created not primarily for the true business and proper functions of a University, but solely in the interests of a degree-granting body, could only have one result. The examination schedules must perforce be within reach of the lower grades of instruction, the various constituent elements would be actively competing bodies, and no attempt to create a single competent staff and a single set of fully-equipped University laboratories would be feasible. Is it at all probable that the true work of a University would flourish under such a system as that? Is it in the least degree likely that we could hope to see created in London, a teaching organization worthy of the greatest and richest capital in the world, or even such as many of the smaller European capitals now possess? The fame of a University, if it is to be anything more than a social function, must depend on the character of its teaching. Would the best men be attracted and retained by such a system? There can be only one answer to these questions. The Gresham scheme is not only a wholly inadequate solution of the University question, but in so far as it tends to accentuate and perpetuate the existing state of things its provisions are positively mischievous. No solution of the question can be either just or final which ignores the existence of the present University of London. If London is to have two degree-granting bodies existing, practically, side by side, we shall have confusion worse confounded. Burlington Gardens would inevitably be driven to establish a teaching organization of its own, unless it was supremely indifferent to its fate or supinely content with the teaching of the Correspondence Colleges and the crammers. Why should we neglect, and not only neglect but positively so arrange as to destroy, the prestige of the existing University of London? This University is not effete-it has still within it a great potentiality for good. Surely, in common gratitude, the University which has hitherto consistently upheld a high standard of attainment for its degrees, and which has NO. 1182 , vol. 46$]$ done so much for the spread of natural science in this country, is worthy of better treatment at the hands of those who profess to minister to the true interests of learning. The Gresham scheme is really an attempt on the part of certain of the medical schools and some of the arts and science teachers to cheapen degrees and so attract students. It is true that the new University medical degrees would carry no license to practise. But is it likely that the University would permanently put up with this unique position, or that its students would continue to submit themselves without a murmur to a double examination system? As the document issued by the Victoria University indicates, the result, in all probability, would be to reduce the two examinations to a single standard by compromise with the licensing body. The scheme, moreover, gives an overwhelming preponderance to the most purely professional of all the faculties, and far too large a share of control to persons of small academic experience who devote occasional spare hours to academic affairs. It makes no attempt to satisfy the demand for the recognition in some form of University work among the people. No wonder, then, that it was strenuously opposed by a powerful section of the governing body, and by a majority of the teachers in the Faculties of Science and Arts, of the most influential College that it proposed to incorporate. The Council of University College, indeed, has never openly ventured to place the scheme before the governing body.

The Gresham University Commissioners are authorized by the terms of their reference "to consider and, if they think fit, to alter and to amend and extend the proposed charter, so as to form . . . a scheme for the establishment, under charter, of an efficient teaching University for London." It is impossible to conceive how the charter submitted to them can be amended so as to form such a scheme if its salient features are preserved. That fact is becoming more and more patent every day. The Association which put forward the proposals we have already referred to now numbers among its membersmedicine excepted-a majority of the leading London teachers. If these teachers say that they do not wish the Gresham Charter at any price, it is difficult to see how it can be imposed upon them. Any attempt to resuscitate that charter, even with amendments, will meet, as before, with the opposition of the provincial Colleges, the minor London teaching bodies, and, what is perhaps more important, the organized opposition of a large section of the London teachers, and of some of the most powerful and influential friends of higher education in this country.

The fact is that it is at last clearly recognized that the foundation of a Metropolitan University, which will bear comparison with those of the great Continental cities, is a matter of national importance. The action of the House of Commons with regard to the Gresham Charter offers an opportunity, such as may not soon occur again, for attempting the formation of a University in London on the same ample lines as those to be found in other European capitals. Watchful observers of what has been going on during the past three or four years have de. liberately come to the conclusion that it is quite impossible to improve the condition of higher education in London by means of any federation of Colleges. The creation of a homogeneous academic body with power to $a b s o r b$, not 
to federate, existing institutions of academic rank, is the only real solution of the problem. An academic body of this character might well be organized, so far as teaching is concerned, on the broad lines of a Scottish University. Such a corporation may be conveniently spoken of as a professorial University, to distinguish it from a federal University. A federal University may be all that is possible when the constituent Colleges are situated in different towns, as is the case in the Victoria University; but it cannot be efficient in London, where these Colleges would appeal to the same public for support.

The scheme put forward by the Association for Promoting a Professorial University for London is not open to the objections urged against the Gresham scheme. It would found a University on the same broad lines as those of France, Germany, and Switzerland. It would bring to the new University all the power and prestige of the existing University. It will meet with no opposition from the provincial Colleges; on the contrary, it has the active support of many of the leading provincial teachers. It satisfies the demands of the Victoria University that the medical degree shall carry the license to practise, and that the medical representation shall not preponderate. It has, for the first time in the history of the movement, brought the most influential teachers from a variety of London teaching bodies into close and active sympathy, and animated them with a desire for a University of definite type. It is significant that the Council and staff of Bedford College are at one in favour of a University on the general lines laid down in the Association scheme. The Senate of University College has carried a motion urging their Council to adopt a similar resolution in favour of the scheme of $a b$ sorption. The Association scheme makes full provision for the recognition of work of the University Extension character, and for the appointment of University lecturers at minor and non-absorbed teaching institutions. Whilst proposing central control and central University laboratories of the highest type, it provides for local teaching such as is required for pass degrees or for the lower stages of honours graduation. Lastly, it provides for post-graduation courses and specialized instruction, such as that of the College de France and of the greater German Universities.

As regards medicine, it recognizes that it is impossible to "absorb" the medical schools owing to their close relation to great public charities; but at the same time it endeavours to grant much of what the Medical Faculty gained by the Gresham Charter. The Medical Faculty will be elected by the medical teachers themselves. There will be, as in every University of standing, medical professors appointed by the Senate from the Medical Faculty on the recommendation of the faculty. The existence of such a medical professoriate will enhance the dignity of the University and of the medical schools, whilst at the same time it holds out a strong inducement to those schools to select members for the Medical Faculty on the ground of their scientific as well as their administrative reputation. The limitation of the number of medical professors on the Senate will safeguard the character of the medical degree. The scheme, whilst giving very extended powers to the medical schools, meets the objections of the provincial opponents of the Gresham Charter. NO. I I 82 , vOL. 46 ]
Lastly, it provides for the due University recognition of the pure science teaching of the medical schools.

We have thus indicated as shortly as possible the main features of the two schemes which are at present before us. The one is essentially parochial in its conception, and vestry-like in its character. The other has in it the elements of a great teaching organization which shall be both metropolitan and imperial in its aims and influence -a University which shall be worthy of London, the capital alike of Great Britain and of the Greater Britain beyond the seas.

\section{THE ANALYSIS OF WINES.}

Analyse des Vins. Par le Dr. L. Magnier de la Source. (Paris: Gauthier-Villars et Fils, 1892.)

$\triangle$ LTHOUGH wine is gradually becoming more and 11 more important as an item in the national drinkbill-last year we imported $16,782,038$ gallons, valued at $£ 5,995, \mathrm{r} 33$-its analysis and the methods for the detection of its sophistication have received comparatively little attention from the chemists of this country. On the other hand, in France and Germany the subject has been very thoroughly investigated in practically all its many details, and carefully worked-out methods have been prescribed for the guidance of the public analysts of those countries. Indeed, there is probably no article of food or drink, with the possible exception of milk, of which the chemistry has been so well thrashed out. Wine is in reality a highly complex fluid, and on account of the character of certain of its proximate constituents it is frequently liable to change. It contains various alcohols, glycerin, acids, salts, "extractive rnatter," together with those principles which give to it its particular colour, special flavour, smell, or "bouquet." Whilst some of these constituents can be accurately isolated and described, others can only be detected by the sense of smell. The principal alcohol is, of course, ethyl alcohol, but butyl and amyl alcohols, together with ethylene glycol and isobutyl glycol are not unfrequently present in greater or less quantity. The quantity of alcohol in natural wines may be said to vary from 6 to I 2 per cent., and the quantity of glycerin from 7 to so per cent. of the alcohol present. Tartaric, malic, succinic, glycollic, and oxalic, together with tannic and acetic, are the chief acids in wine. These are said to aid in its preservation, by preventing the formation of fungi. Traces of other fatty acids, such as propionic, butyric, and œnanthic acids are also present, as well as acetaldehyde, and possibly its homologues. Tartaric acid occurs mainly as the dextro variety : lævo-tartaric acid is only of comparatively infrequent occurrence. If tartaric acid is not found, as, for example, in certain samples of sherry, its absence is almost certainly due to its removal by "plastering." The amount of free acid in sound wine, reckoned as tartaric acid, varies between 0.3 and 0.7 per cent.; a greater amount than this imparts sourness to the wine.

Old wines have an acid reaction in consequence of the presence of a certain amount of free acid and potassium bitartrate. A wine not exhibiting this acid reaction tastes flat ; the acidity is its most important flavour. For a long time it has been believed that the free acid of 